NASA/TM-2002-211573

\title{
Duct Mode Measurements on the TFE731-60 Full Scale Engine
}

Daniel L. Sutliff

SEST, Inc., Middleburg Heights, Ohio

Kevin E. Konno and Laurence J. Heidelberg

Glenn Research Center, Cleveland, Ohio 
Since its founding, NASA has been dedicated to the advancement of aeronautics and space science. The NASA Scientific and Technical Information (STI) Program Office plays a key part in helping NASA maintain this important role.

The NASA STI Program Office is operated by Langley Research Center, the Lead Center for NASA's scientific and technical information. The NASA STI Program Office provides access to the NASA STI Database, the largest collection of aeronautical and space science STI in the world. The Program Office is also NASA's institutional mechanism for disseminating the results of its research and development activities. These results are published by NASA in the NASA STI Report Series, which includes the following report types:

- $\quad$ TECHNICAL PUBLICATION. Reports of completed research or a major significant phase of research that present the results of NASA programs and include extensive data or theoretical analysis. Includes compilations of significant scientific and technical data and information deemed to be of continuing reference value. NASA's counterpart of peerreviewed formal professional papers but has less stringent limitations on manuscript length and extent of graphic presentations.

- TECHNICAL MEMORANDUM. Scientific and technical findings that are preliminary or of specialized interest, e.g., quick release reports, working papers, and bibliographies that contain minimal annotation. Does not contain extensive analysis.

- CONTRACTOR REPORT. Scientific and technical findings by NASA-sponsored contractors and grantees.
- CONFERENCE PUBLICATION. Collected papers from scientific and technical conferences, symposia, seminars, or other meetings sponsored or cosponsored by NASA.

- SPECIAL PUBLICATION. Scientific, technical, or historical information from NASA programs, projects, and missions, often concerned with subjects having substantial public interest.

- TECHNICAL TRANSLATION. Englishlanguage translations of foreign scientific and technical material pertinent to NASA's mission.

Specialized services that complement the STI Program Office's diverse offerings include creating custom thesauri, building customized data bases, organizing and publishing research results ... even providing videos.

For more information about the NASA STI Program Office, see the following:

- Access the NASA STI Program Home Page at http://www.sti.nasa.gov

- E-mail your question via the Internet to help@sti.nasa.gov

- Fax your question to the NASA Access Help Desk at 301-621-0134

- Telephone the NASA Access Help Desk at 301-621-0390

- Write to:

NASA Access Help Desk

NASA Center for AeroSpace Information 7121 Standard Drive

Hanover, MD 21076 
NASA/TM-2002-211573

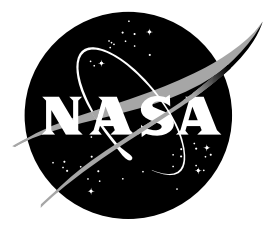

\section{Duct Mode Measurements on the TFE731-60 Full Scale Engine}

Daniel L. Sutliff

SEST, Inc., Middleburg Heights, Ohio

Kevin E. Konno and Laurence J. Heidelberg

Glenn Research Center, Cleveland, Ohio

Prepared for the

Eighth Aeroacoustics Conference

cosponsored by the American Institute of Aeronautics and Astronautics and the Confederation of European Aerospace Societies

Breckenridge, Colorado, June 17-19, 2002

National Aeronautics and

Space Administration

Glenn Research Center

May 2002 


\section{Acknowledgments}

This work was done as a part of a contract with Honeywell Engines and Systems, NAS3-97151. Rotating Rake hardware was developed by Aerospace Design Fabrication, Inc. under NAS3-27600 by George Pinkas and Ray Homyk. The reporting and analysis was under contract NAS3-00170, SEST, Inc. The contributions of Kevin Detreich, Dale Brock, and Gary Meshew at the San Tan facility were vital.

Available from

NASA Center for Aerospace Information 7121 Standard Drive

Hanover, MD 21076
National Technical Information Service 5285 Port Royal Road Springfield, VA 22100

Available electronically at http://gltrs.grc.nasa.gov/GLTRS 


\title{
DUCT MODE MEASUREMENTS ON THE TFE731-60 FULL SCALE ENGINE
}

\author{
Daniel L. Sutliff* \\ SEST, Inc. \\ Middleburg Heights, Ohio 44130
}

Kevin E. Konno ${ }^{\dagger}$ and Laurence J. Heidelberg ${ }^{\ddagger}$

National Aeronautics and Space Administration

Glenn Research Center

Cleveland, Ohio 44135

\begin{abstract}
$\underline{\text { Abstract }}$
A continuously rotating rake with radial microphones was developed to measure the inlet and exhaust duct modes on a TFE731-60 turbofan engine. This was the first time the rotating rake technology was used on a production engine. The modal signature for the first three fan harmonics was obtained in the inlet and exhaust. Rotor-stator and rotor-strut interaction modes were measured. Total harmonic power was calculated over a range of fan speeds. Above sonic tip speed, the rotor locked mode was not strong enough to be identified, but the "buzz-saw" noise at fan subharmonics was identified.
\end{abstract}

\section{Introduction}

The Advanced Subsonic Technology (AST) program sponsored the Engine Validation of Noise Reduction Concepts (EVNRC). A full-scale turbofan engine, the TFE731-60 was used as a test bed for part of this program. A continuously rotating rake with radially distributed microphones was developed for use on the Honeywell TFE731-60 as an acoustic diagnostic tool. Rotating rake technology had been developed and used successfully on model scale ${ }^{1}$ and a dedicated test bed. ${ }^{2}$ The test was accomplished in two separate, repeated, entries during June and August 1999.

\section{Experimental Apparatus}

\section{TFE731-60 Turbofan Engine}

A TFE731-60 engine with accompanying reference inlet and nozzle was used for this test. Basic engine information is described in table 1. The TFE731-60 has 22 rotor blades and 52 stator blades. The rotor-stator interaction mode at blade passing frequency (BPF) is cut-off below sonic rotor tip speed. The engine was tested at the Honeywell engine test stand in San Tan,

\footnotetext{
"Senior Aeroacoustics Researcher, Senior Member AIAA

Aerospace Engineer

Aerospace Engineer, Senior Member AIAA
}

Arizona. A photograph of the engine on the test stand, and a schematic of the fan flow-path are shown in figure 1 .

\section{$\underline{\text { Rotating Rake }}$}

\section{Methodology}

The classic paper by Tyler and Sofrin ${ }^{3}$ presents the theory of fan-duct mode generation and propagation. The generation of circumferential spinning modes is governed by the following equation:

$$
\mathrm{m}=\mathrm{sB} \pm \mathrm{kV}
$$

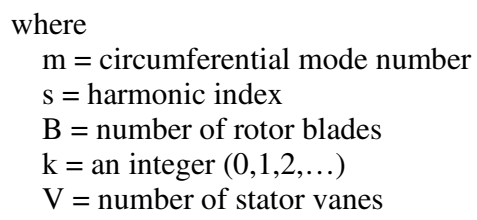

The rotor locked, or rotor alone, mode $(\mathrm{m}=\mathrm{sB})$ spins at the shaft rotation speed. It is the potential field of the rotor. Separate rotor-stator and rotor-strut interaction modes also exists at the same m-order, when $\mathrm{k}=0$. These modes, and higher order modes, can only propagate in a narrow annular duct if the blade tip speed which correspond to their spin rate is above Mach $=1.0$. Lower order modes, which spin faster, may propagate if their spin rate results in sonic speed. The critical tip Mach number is slightly greater than 1.0 for non-narrow annular ducts. The spin rate of a circumferential mode is determined by the following equation:

$$
\Omega \mathrm{m}=\mathrm{sB} \Omega / \mathrm{m}
$$

where:

$\Omega \mathrm{m}=$ mode rotation speed

$\Omega=$ shaft rotation speed 
Each circumferential mode, $\mathrm{m}$, can have one or more radial modes, $n$. Mode propagation is dependent on the cut-off frequency, which is unique to each $(m, n)$ mode. This frequency is dependent on geometric parameters and the eigenvalue of a combined Bessel function that is a solution to the cylindrical wave equation. Below the cut-off frequency the mode will decay exponentially. Above cut-off, propagation occurs and acoustic power is transmitted down the duct and into the farfield. The cut-off frequency is given by:

$$
\mathrm{f}_{\mathrm{co}}=\hat{\mathrm{e}} \mathrm{c} / \pi \mathrm{D}
$$

$$
\begin{aligned}
& \text { where: } \\
& f_{\text {co }}=\text { cut-off frequency } \\
& \hat{\mathrm{e}}=\text { bessel function eigenvalue } \\
& \mathrm{c}=\text { speed of sound } \\
& \mathrm{D}=\text { duct diameter }
\end{aligned}
$$

The Bessel function eigenvalue incorporates the duct geometry effects. The cut off ratio gives the ratio of the mode frequency to its cut-off frequency.

$$
\zeta=f / f_{\mathrm{co}}=\pi \mathrm{sB}(\Omega \mathrm{m}) \mathrm{D} / 60 \mathrm{êc}
$$

The rotating rake instrumentation system provides a complete map of the duct modal signature at $1 \mathrm{BPF}$, $2 \mathrm{BPF}$, and $3 \mathrm{BPF}$ (blade passing frequency) for either the inlet or the exhaust duct. ${ }^{4}$ The resolution of circumferential modes arise from a Doppler induced frequency shift due to the unique and discrete rotation rate of each m-order imparted by the continuous rotation of the rake. ${ }^{5}$ Radial modes are computed from a least squares data fit of the radial pressure profile using the hardwall Bessel functions as the basis functions. ${ }^{6}$

The modal data from the rotating rake are presented in 3-D format. The base plane axes are $\mathrm{m}$ - and $\mathrm{n}$-order, and the vertical value axis in the PWL in the $(m, n)$ mode. Along the wall of the m-order axis the sum of all the radials provides the power in that circumferential mode. The sum of all provides the PWL in the harmonic presented. A typical modal decomposition provides information as to the dominant modes present, usually those due to the rotor stator interaction. Of secondary interest will be other modes, which may be due to inflow distortions or other geometric disturbances.

The circumferential rotor-stator interaction modes for the first three blade passing frequencies are presented in table $2 \mathrm{a}$. In addition, there are 10 downstream exhaust struts that could produce Tyler-Sofrin type interaction modes shown on table $2 \mathrm{~b}$.

\section{Hardware}

The rake acquires pressure data as it spins around the nacelle using a series of radially distributed pressure transducers pointing at the fan. The rake is used in two locations-the inlet and the exhaust. The inlet rake rotates around the duct centerline inside the nacelle at the throat. At the nozzle, the rake rotates at the exit plane of the bypass duct. Photographs and schematic drawings of the rakes are shown on figure 2. The rotating parts are shown in red while the stationary parts are blue. Both rakes have windscreens covering the transducers to: lower vortex shedding noise from the inlet rake; and lower interaction with the viscous wake for the exhaust rake.

The rotational speed of the rake was required to be a specific whole number fraction, i.e., 1/200 in this case, of the TFE731-60 fan shaft speed and in phase with the shaft. This means that when the fan has rotated 200 times, the rotating rake will have completed exactly one revolution in that time span within $\pm 0.2^{\circ}$. This speed and phase synchronization is necessary in order to resolve the Doppler induced frequency shift of the spinning acoustic modes. Consequently, the rake requires a very accurate drive and control system. This accuracy must also be repeated over the entire test period (five to ten minutes) without build-up of phase error. The rake must follow the fan precisely even though the fan will wander in speed (5 to $10 \mathrm{rpm}$ or so) throughout the test period. Consequently, the rake drive system must be slaved directly to the fan. Table 3 contains a list of rake control system performance requirements.

The inlet installation was a design challenge, since the whole rotating rake mechanism had to fit inside the Inflow Control Device (ICD). An ICD is used to eliminate the ground vortex and reduce the incoming atmospheric turbulence thus simulating in-flight noise during static testing.

\section{Test Conditions}

Rotating Rake measurements were taken over a fan speed range of approximately 6000 to $10000 \mathrm{rpm}$. Nominal data points were taken at $60,64,67,75,81$, 88, and 94 percent of $\mathrm{N} 1 C_{\max }$. The TFE731-60 is a geared fan with a ratio of 2.0645 so that $\mathrm{N} 1 \mathrm{C} \max$ corresponds to $\mathrm{Nf}_{\max }=10,172 \mathrm{rpm} ; \mathrm{V}_{\text {tip }}=1362 \mathrm{fps}$. Approach is 64 percent $\mathrm{N} 1 \mathrm{C}\left(\mathrm{V}_{\text {tip }}=872 \mathrm{fps}\right)$, cutback is 81 percent $\mathrm{N} 1 \mathrm{C}\left(\mathrm{V}_{\text {tip }}=1104 \mathrm{fps}\right)$. Due to operational constraints 81 percent was not achievable; 78 percent N1C was substituted. Points at 88 percent and above represent supersonic rotor tip speeds.

Two entries, separated by a major configuration change, were tested. A major difference between the two entries was that for the first entry the engine was side mounted, allowing the engine to pitch up with increasing thrust, causing the rotating rake to no longer rotate about the engine centerline. This may have caused an inaccuracy in the inlet measurements due to 
positioning error, which was not quantified. For the second entry, the engine was top mounted, reducing the pitch-up with thrust considerably.

\section{$\underline{\text { Results and Discussion }}$}

The complete mode map (circumferential and radial) for the inlet and exhaust ducts for the first blade passing harmonic at $60 \% \mathrm{~N} 1 \mathrm{C}$ are shown on figure 3 . The measurement noise floor is estimated to be about $95 \mathrm{~dB}$. The inlet modes are dominated by the co-rotating (positive) spinning modes. This is because the contrarotating modes are blocked by the rotor. ${ }^{7}$ The exhaust mode distribution is more uniformly distributed between the co- and contra-rotating modes. The overall PWLs are 114.8 in the inlet, and $115.2 \mathrm{~dB}$ in the exhaust. While the rotor-stator interaction mode is cutoff at BPF below sonic rotor tip speed, the rotor-strutmodes are cut-on. These strut modes are identifiable, but their contribution to the overall PWL is minor as can be seen by comparing the sum of the strut mode PWL to the overall PWL.

The m-order distribution for the high speed ( 88 percent $\mathrm{N} 1 \mathrm{C}$ ) is shown on figure 4. (The complete mode-map is available, but the density prevented meaningful display.) At this speed, the rotor locked mode $(\mathrm{m}=22)$ is cut-on. The inlet shows the increase in the $\mathrm{m}=22$ and the neighboring modes. Recall that the $m=22$ mode is actually the sum of the rotor-locked mode, the rotorstator interaction mode $(\mathrm{k}=0)$, the rotor-strut interaction mode, and the rake wake interference mode. The exhaust shows a general increase in all modes with the rotor-strut interaction modes showing a modest dominance over the non Tyler-Sofrin interaction modes, or extraneous modes.

Figure 5 summarizes the strut modes and the total harmonic power levels versus $\% \mathrm{~N} 1 \mathrm{C}$ for BPF. In the subsonic tip regime, the PWL is dominated by the sum of the extraneous modes. The cut-on of the $\mathrm{m}=22$ modes above a sonic tip speed contributes to a $15 \mathrm{~dB}$ increase in the overall PWL.

Figure 6 shows the m-order distribution for $2 \mathrm{xBPF}$ for 60 percent N1C. The rotor-vane interaction is the $\mathrm{m}=-8$. This mode is almost $10 \mathrm{~dB}$ higher than the other modes, though in the inlet it is considerably lower due to rotor blockage. At the 88 percent N1C, (figure 7), the inlet shows a strong $m=-14$ and $m=+14$. Though the $\mathrm{m}=+14$ is a strut mode, neither mode is strongly present at other speeds. In general, the rotor-strut modes at $2 \mathrm{BPF}$ do not rise above the extraneous mode levels.

Figure 8 shows that at $2 \mathrm{BPF}$ the PWL is exhaust dominated by 5 to $10 \mathrm{~dB}$. In the exhaust, the rotor-vane interaction mode is a significant contributor to the overall PWL, only 3 to $6 \mathrm{~dB}$ below. The second harmonic of the rotor-locked mode $(m=44)$ is not significant.

The two separate test entries, separated by a major configuration change, allowed for a determination of the repeatability of the mode measurement technique. Figure 9 shows the repeatability for two runs for each entry. The BPF rotor-strut-interaction modes agree to within a few $\mathrm{dB}$. For the strong rotor-vane interaction mode at $2 \mathrm{BPF}$, the m-order repeatability is within $1 \mathrm{~dB}$. The individual radials show good repeatability with the stronger radials demonstrating closer agreement. Other speeds demonstrated similar repeatability.

The rotor-locked mode $(\mathrm{m}=22$ at $\mathrm{BPF})$ cuts on at 8341 rpmc. As discussed before, this mode is contaminated by the rake-wake rotor interaction. For the subsonic rotor speeds the rake-wake rotor interference which shows up at $\mathrm{m}=22$ is the only mode that should be measured at $m=22$. Therefore it may be possible to draw a qualitative conclusion about the rotor-locked mode by comparing the levels of $\mathrm{m}=22$ above and below cut-on as in figure 10a. Since the $\mathrm{m}=22$ mode changes very little as the rotor-locked is cut-on it is assumed that what is being measured by the rake is mostly the interference mode, and that the rotorlocked mode is not distinguishable from the interference. For comparison, the $\mathrm{m}=22$ mode measured in exhaust is shown, and the clear increase as the combined modes at $\mathrm{m}=22$ is observed. (There is no rotor wake contamination with the rake in the exhaust.)

The lower shaft-orders $(21,20,19 \ldots 1)$ also contribute to the "buzz-saw" noise generated near sonic tip speed. The mode generated at each shaft-order is numerically identical, i.e., at the 20th shaft order the $m=20$ mode is generated. Figures $10 \mathrm{~b}$ and $10 \mathrm{c}$ show m-order contribution for all shaft orders below BPF. The highest levels occur at shaft-orders 11 to 15 . As a result of the eigenvalues, at the lower shaft-order/m-order $(\mathrm{so} / \mathrm{m})$ the cut-off ratio actually decreases, to the point that for so/m 13 and below the mode is classically cut-off. This is part of the reason for the mode pressure rise at $\mathrm{so} / \mathrm{m}=14$. However, Mach number effects cause propagation of these lower shaft-order/m-orders.

\section{$\underline{\text { Conclusions }}$}

The first Rotating Rake mode measurements were taken on a full-scale turbofan engine, the TFE731-60. The rotor-strut interaction modes at BPF were identified as the dominant modes but were to be a minor contribution to overall PWL, due to the strength of the extraneous (background) modes. Rotor transmission losses were shown to result in lower co-rotating modes in the inlet. The $2 \mathrm{BPF}$ rotor-vane interaction mode was clearly identified in the inlet and exhaust, and observed to dominate. 
Repeatability of the measurements was shown to be excellent by comparing results from two separate test builds.

An attempt to measure the rotor-locked noise was inconclusive though some information showed the subharmonics ("buzz-saw") to be dominated by the shaftorders just under 1/2 BPF.

\section{$\underline{\text { References }}$}

1. Heidelberg, L.J., and Hall, D.G., "Inlet Acoustic Mode Measurements Using a Continuously Rotating Rake," Journal of Aircraft, pp. 761-767, July-August 1995.

2. Heidelberg, L.J., Hall, D.G., Bridges, J.E., and Nallasamy, M., "A Unique Ducted Fan Test Bed for Active Noise Control and Aeroacoustics Research," NASA TM-107213, AIAA 96-1740, May 1996.

3. Tyler J.M., and Sofrin T.G., "Axial Flow Compressor Noise Studies," SAE Transactions, vol. 70, 1962, pp. 309-332.

4. Sutliff, D.L., Nallasamy, M., Heidelberg, L.J., and Elliott, D.M., "Baseline Acoustic Levels of the NASA Active Noise Control Fan Rig," NASA TM-107214, AIAA 96-1745, May 1996.

5. Hall, D.G., Heidelberg, L.H., and Konno, K., "Acoustic Mode Measurements in the Inlet of a Model Turbofan Using a Continuously Rotating Rake: Data Collection/Analysis Techniques." NASA TM-105936, January 1993, also AIAA 930599, January 1993.

6. Moore, C.J., "Measurement of Radial and Circumferential Modes in Annular and Circular Ducts," Journal of Sound and Vibration, vol. 62, no. 2, 1979, pp. 235-256.

7. Hanson, D.B., "Acoustic Reflection and Transmission of Rotor and Stators Including Mode and Frequency Scattering," AIAA/CEAS 97-1610, May 1997.
Table 1. TFE731-60 engine parameters

\begin{tabular}{|l|c|}
\hline Basic Engine Weight & $988 \mathrm{lb}$ \\
\hline Takeoff, Sea Level, Static Thrust & $5000 \mathrm{lb}$ \\
\hline Airflow & $187 \mathrm{lb} / \mathrm{sec}$ \\
\hline Cruise Bypass Ratio & 3.9 \\
\hline Cycle Pressure Ratio & 22 \\
\hline Geared Fan Pressure Ratio & 1.70 \\
\hline
\end{tabular}

Table 2a. Rotor-stator interaction modes

\begin{tabular}{|l|c|}
\hline Harmonic & Interaction modes \\
\hline $1 \mathrm{BPF}$ & $2 *$ \\
\hline $2 \mathrm{BPF}$ & $44,-8$ \\
\hline $3 \mathrm{BPF}$ & 66,14 \\
\hline
\end{tabular}

*cut-off at subsonic speeds

Table 2b. Rotor-strut interaction modes

\begin{tabular}{|l|c|}
\hline Harmonic & Interaction modes \\
\hline 1BPF & $22,12,2,-8,-18$ \\
\hline $2 \mathrm{BPF}$ & $44,34,24,14,4,-6,-16,-26,-36$ \\
\hline \multirow{2}{*}{$3 \mathrm{BPF}$} & $66,56,46,36,26,16,6$, \\
& $-4,-14,-24,-34,-44,-54,-64$ \\
\hline
\end{tabular}

Table 3. Rake design parameters

\begin{tabular}{|c|c|}
\hline Maximum fan speed & $10,000 \mathrm{rpm}$ \\
\hline Rake speed ratio & $1 / 200$ \\
\hline Maximum rake speed & $50 \mathrm{rpm}$ \\
\hline $\begin{array}{l}\text { Accuracy of fan-following } \\
\text { rake speed }\end{array}$ & $\pm 0.2^{\circ}$ of rake rotation \\
\hline Test point duration & 10 minutes \\
\hline Number of microphones & $\begin{array}{l}\text { Inlet: } 14 \\
\text { Nozzle: } 8\end{array}$ \\
\hline Max duct flow (M\#) & $\begin{array}{cc}\text { Inlet: } 0.60 \\
\text { Nozzle } 0.85\end{array}$ \\
\hline
\end{tabular}




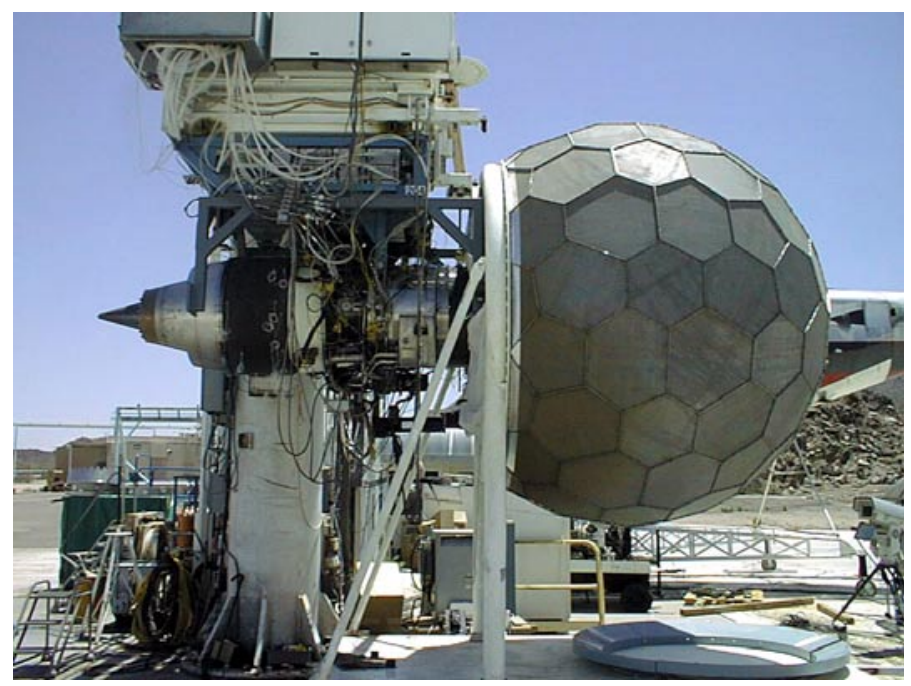

(a) Photograph of TFE731-60 engine on Honeywell test stand

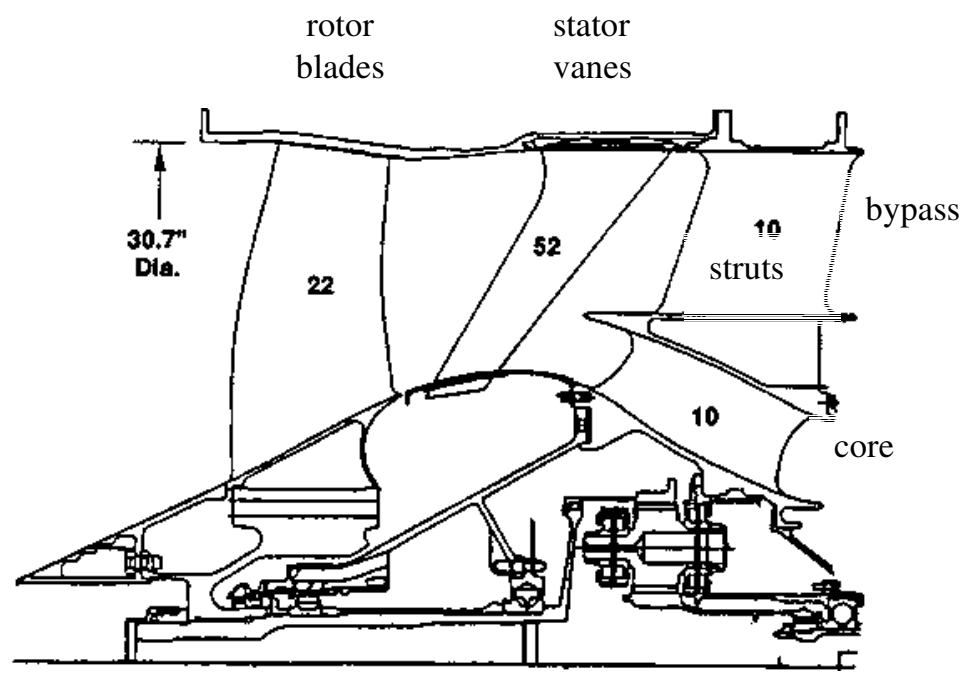

(b) Schematic of fan flow-path

Figure 1. Honeywell TFE731-60 Engine 

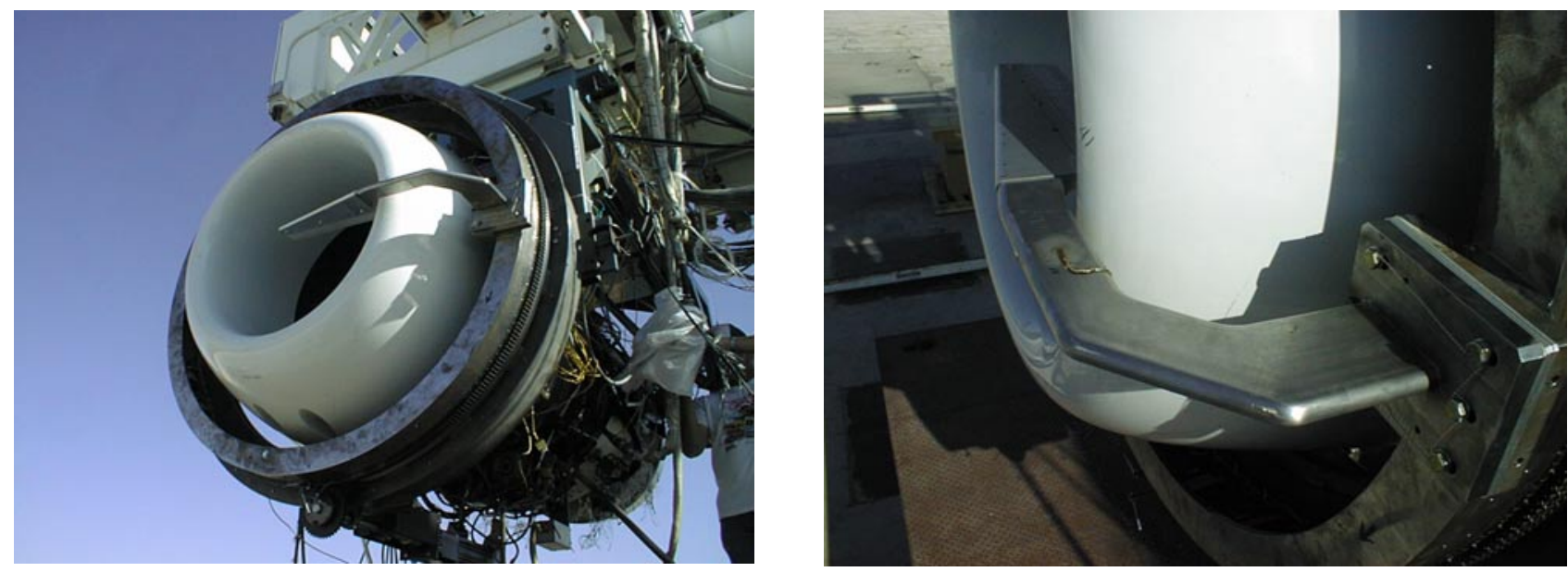

(a) Photographs of inlet rake installed on TFE731-60 engine

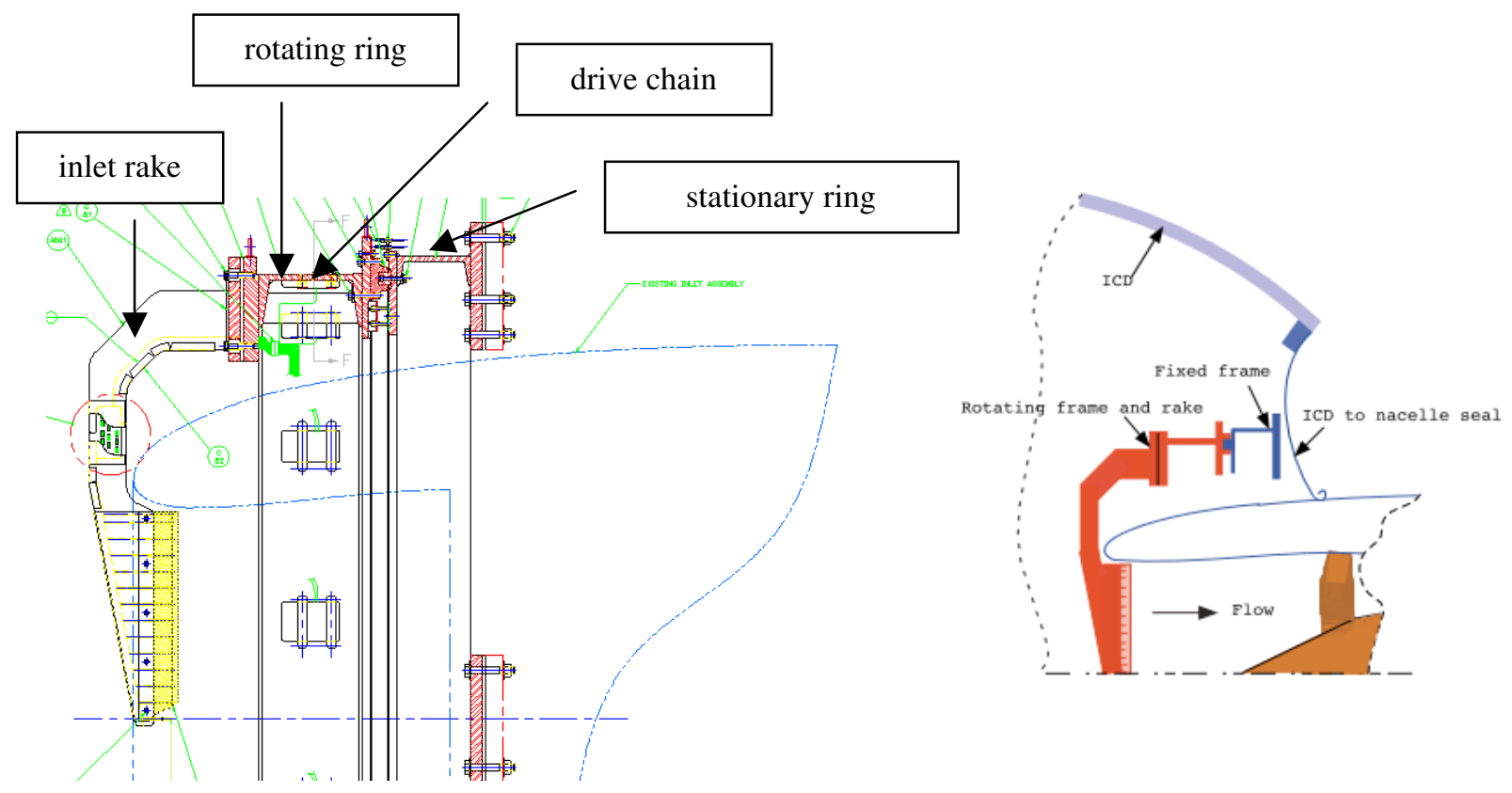

(b) Schematic side view of inlet rake assembly

Figure 2. Photographs of rakes installed on TFE731-60 engine 

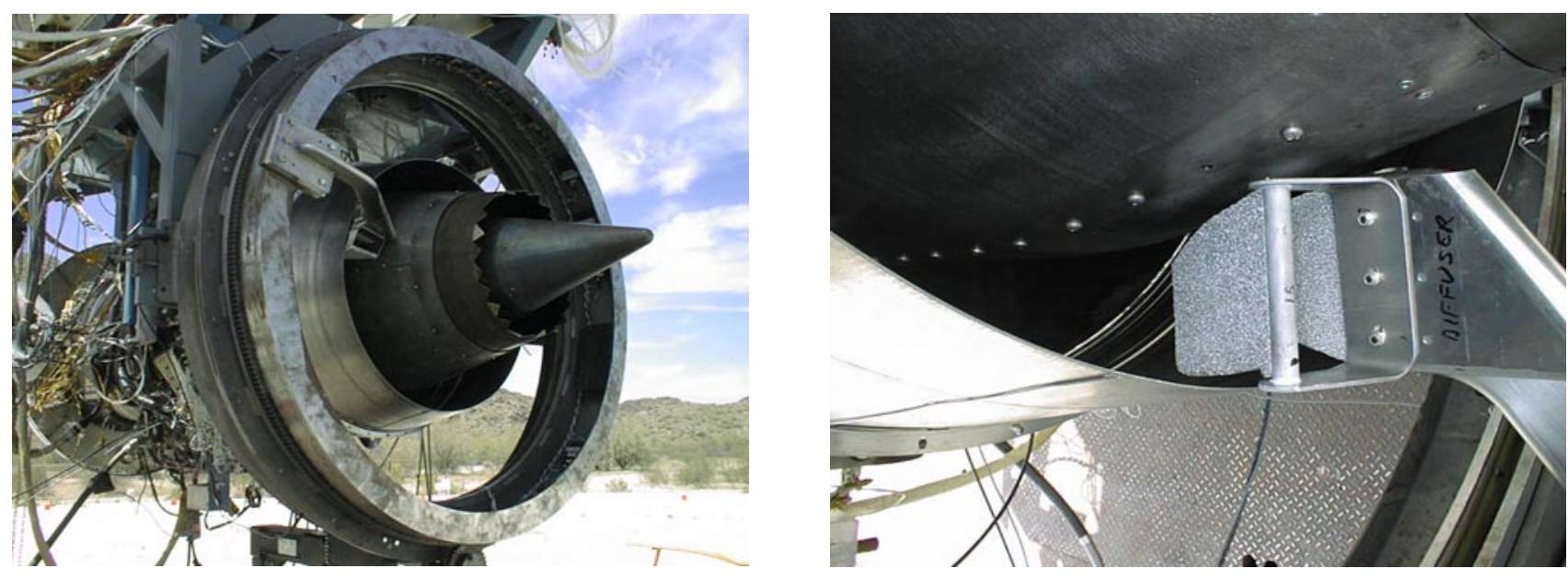

(c) Photographs of exhaust rake installed on TFE731-60 engine

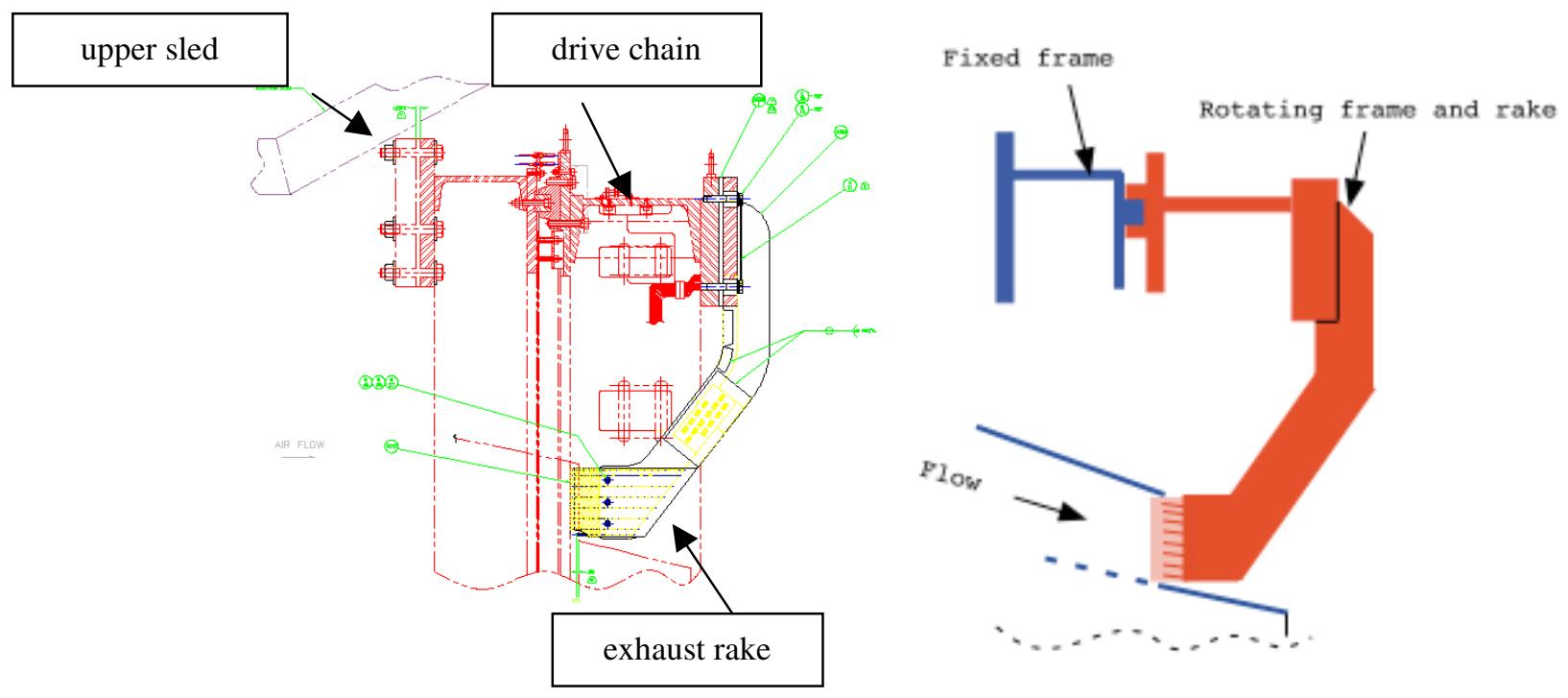

(d) Schematic side view of exhaust rake assembly

Figure 2. Photographs of rakes installed on TFE731-60 engine (concluded) 

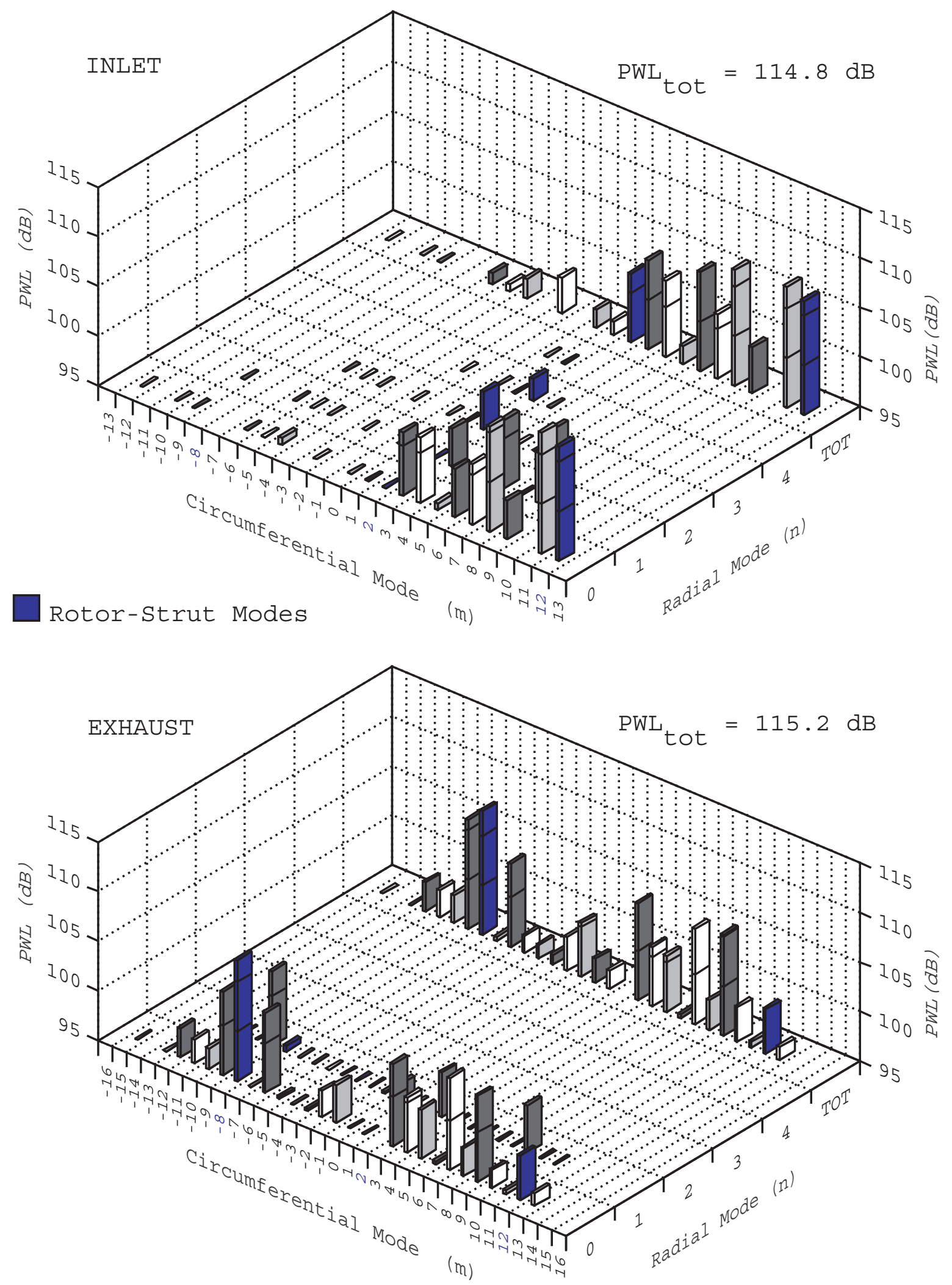

Figure 3. Mode map for $60 \%$ N1C, 1 xBPF 


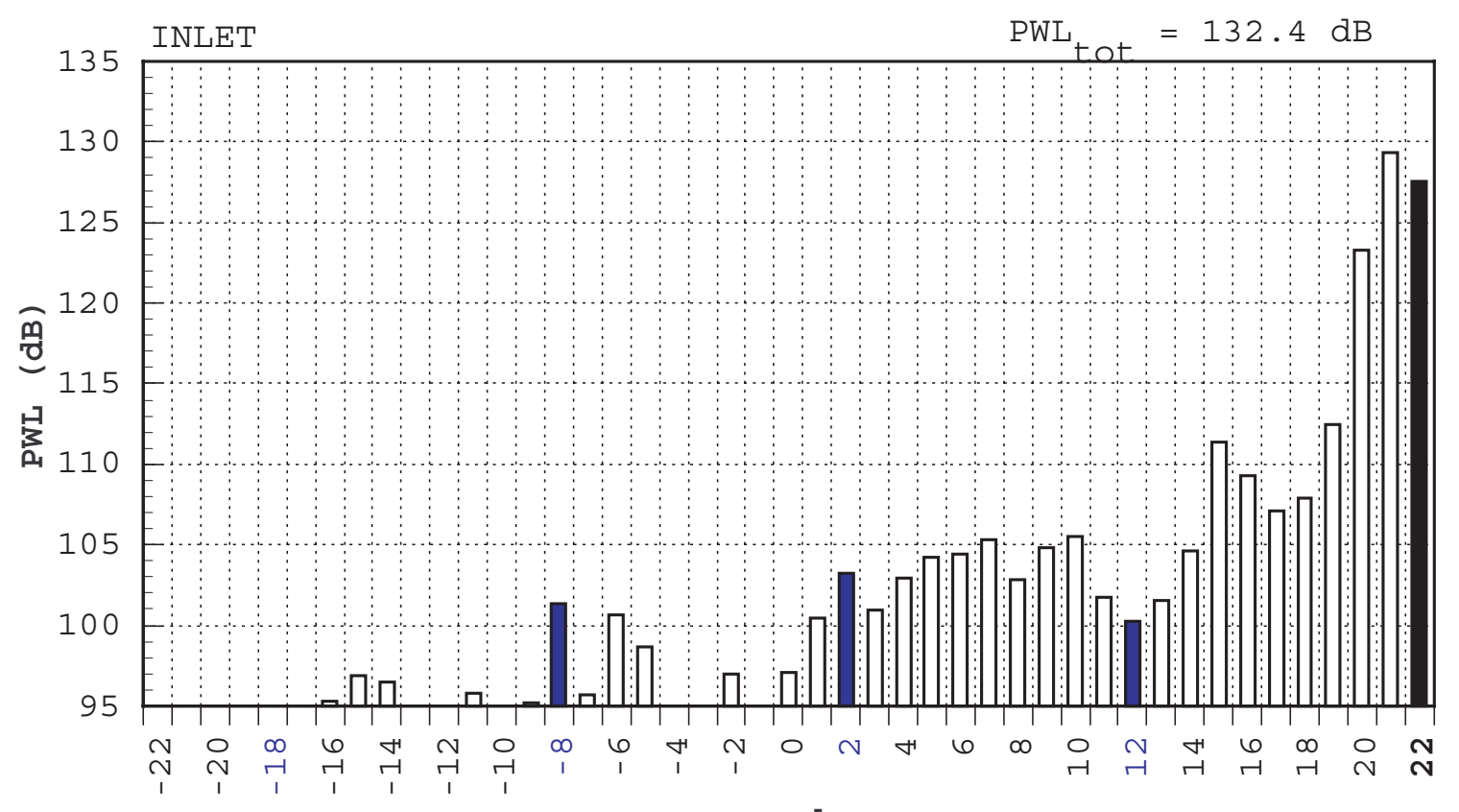

m-order

Rotor-Strut Modes

Combined Modes

(rotor-locked, rotor-

stator, rotor-vane, and

rake wake interference)

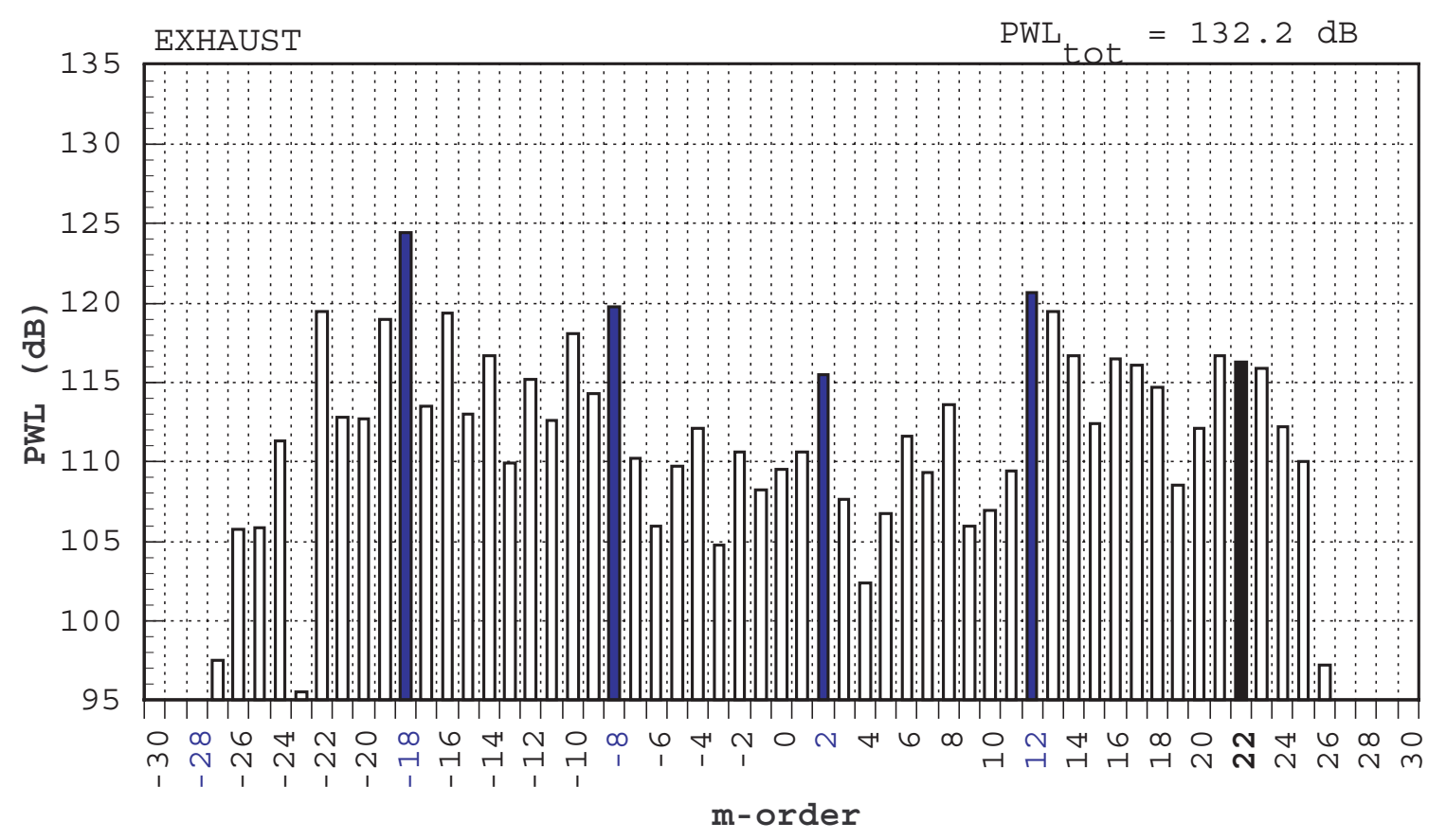

Figure 4. Mode map for $88 \%$ N1C, 1xBPF 

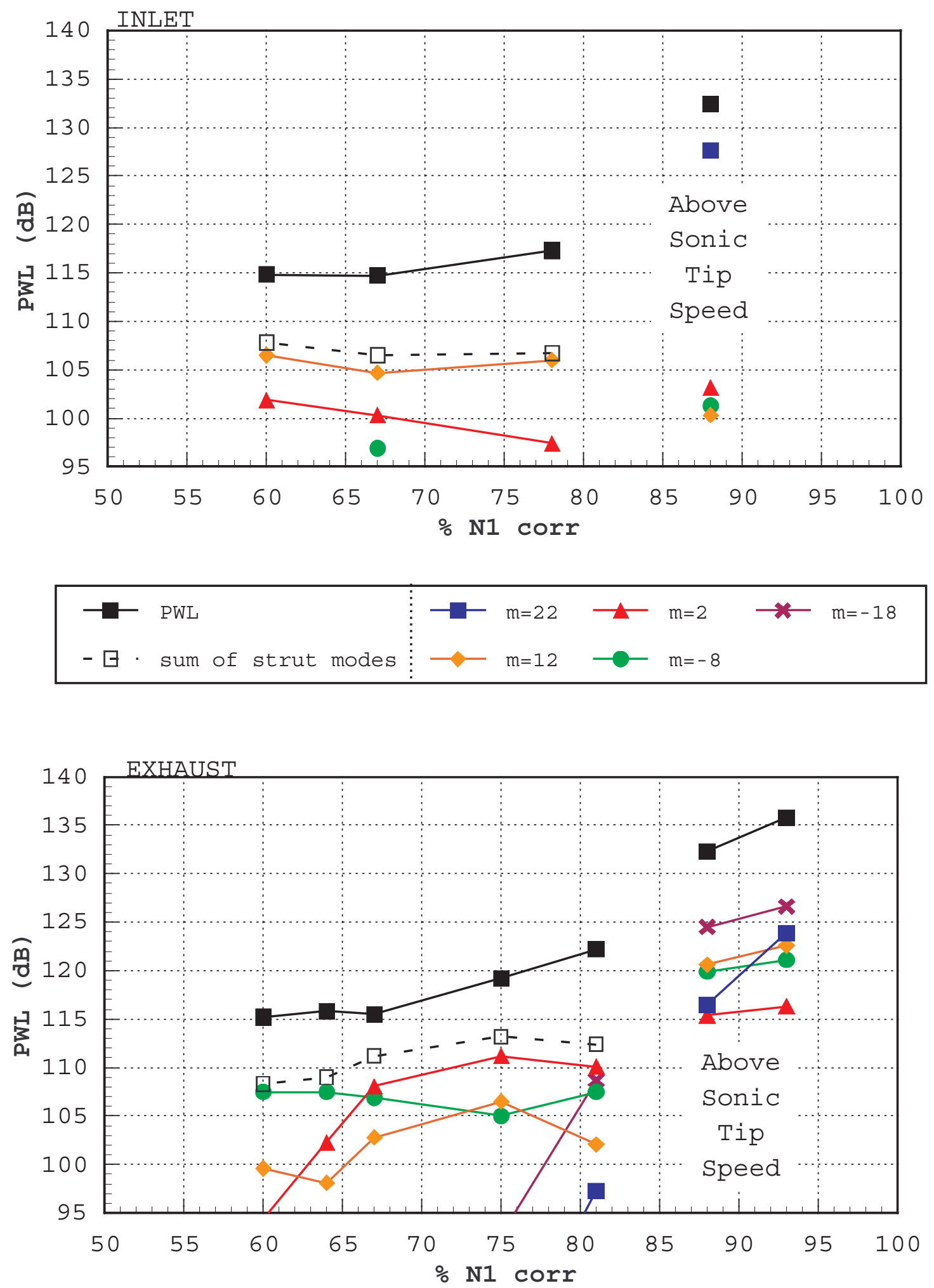

Figure 5. Total harmonic power versus corrected percent speed, 1xBPF 

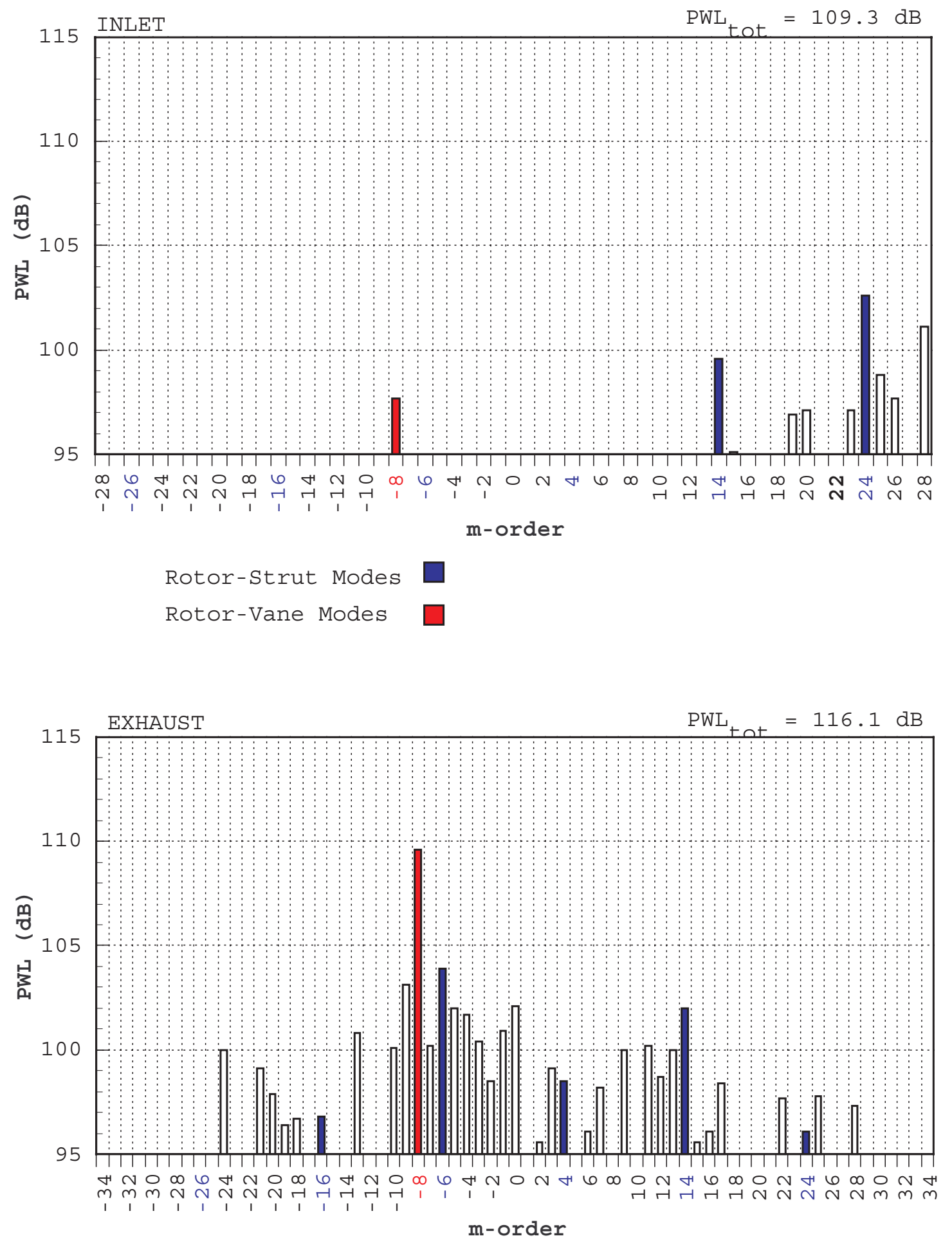

Figure 6. Mode map for $60 \%$ N1C, 2 XBPF 

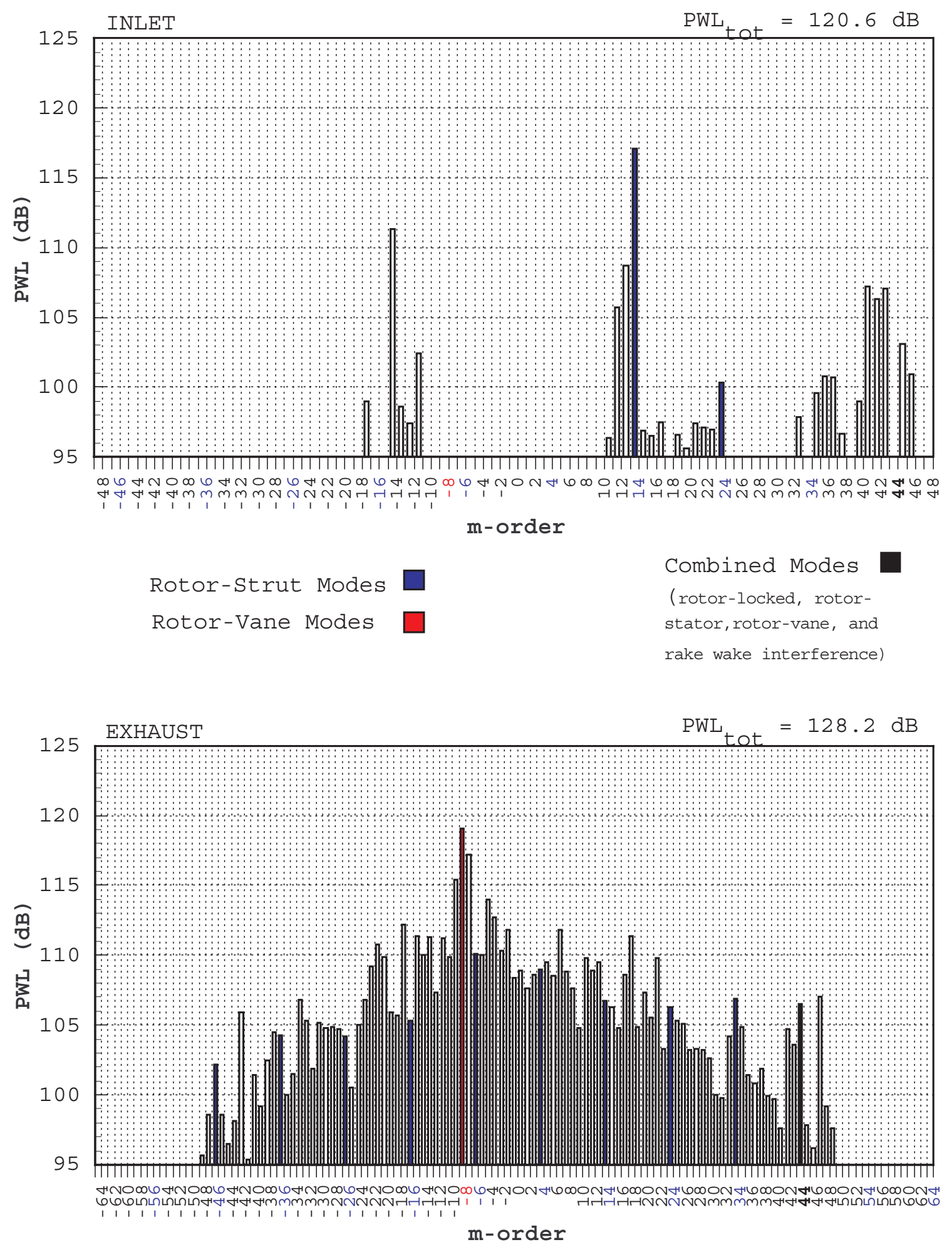

Figure 7. Mode map for $88 \%$ N1C, 2 xBPF 


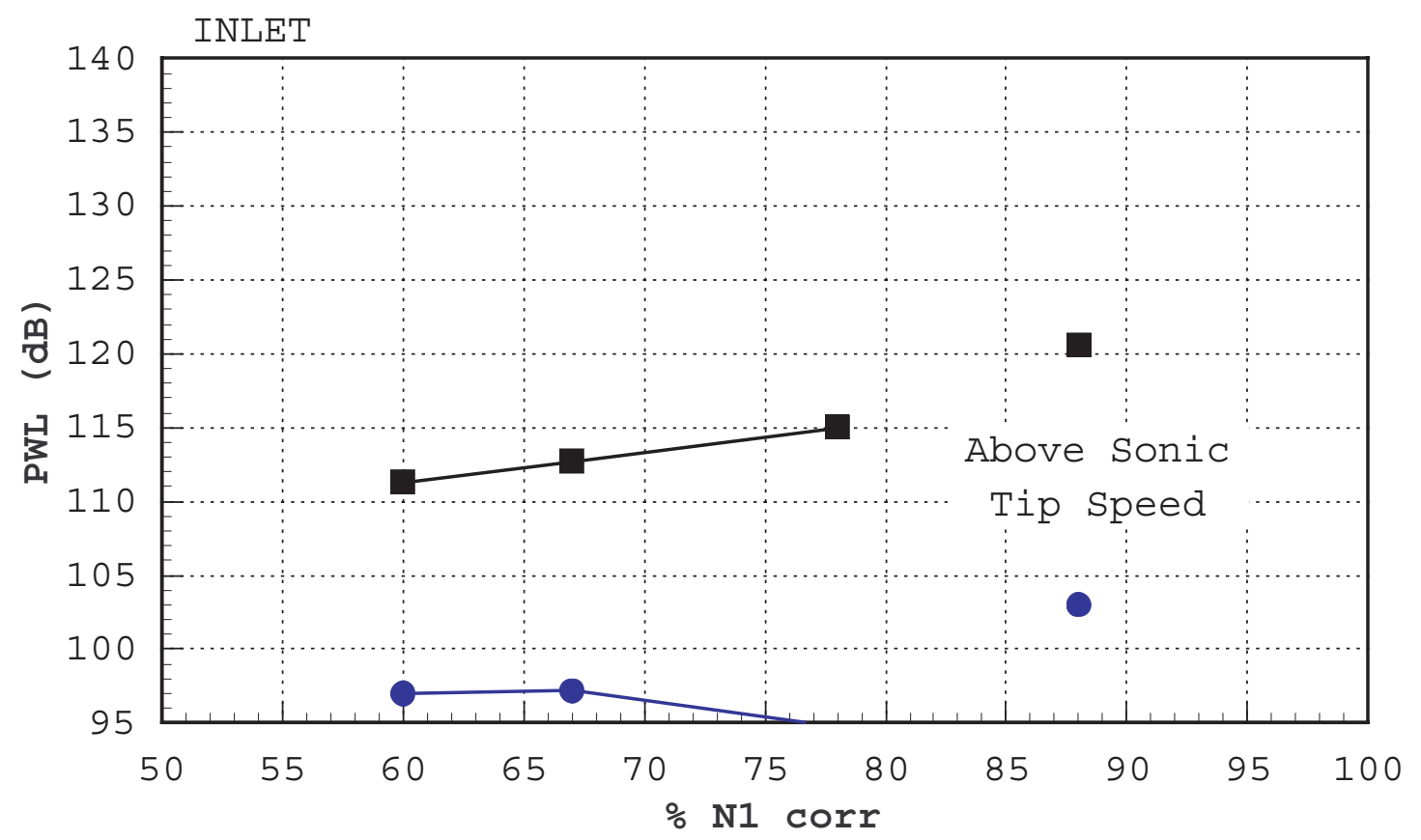

$$
\multimap \mathrm{m}=-8 \longrightarrow \mathrm{m}=44 \quad \longrightarrow \mathrm{PWL}
$$

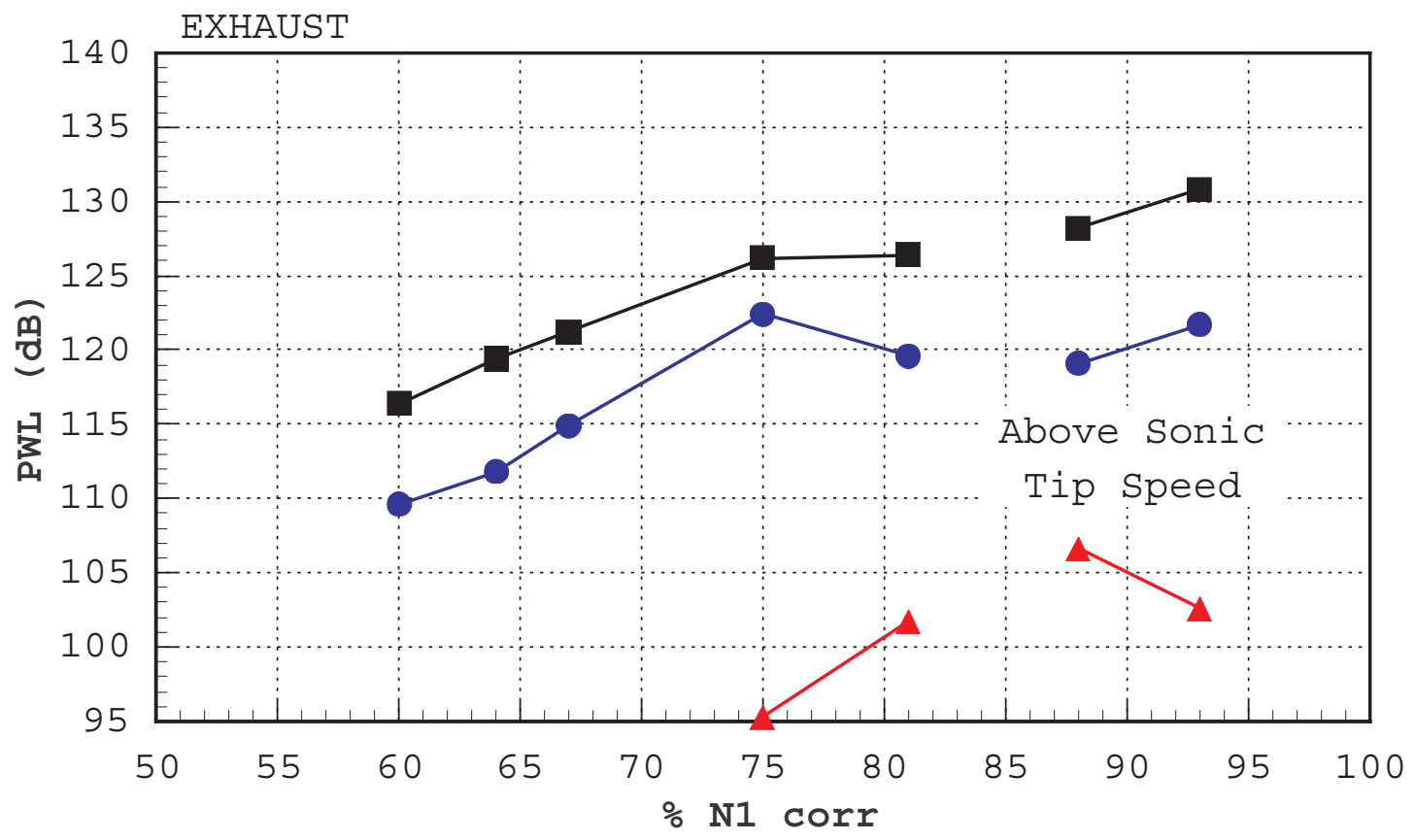

Figure 8. Total harmonic power versus N1C, 2xBPF 


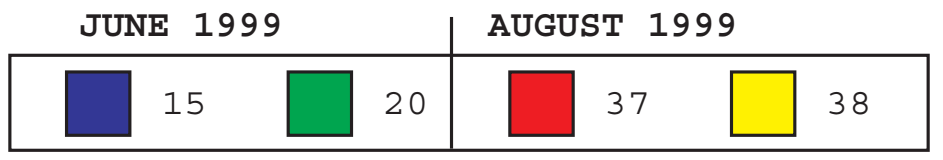

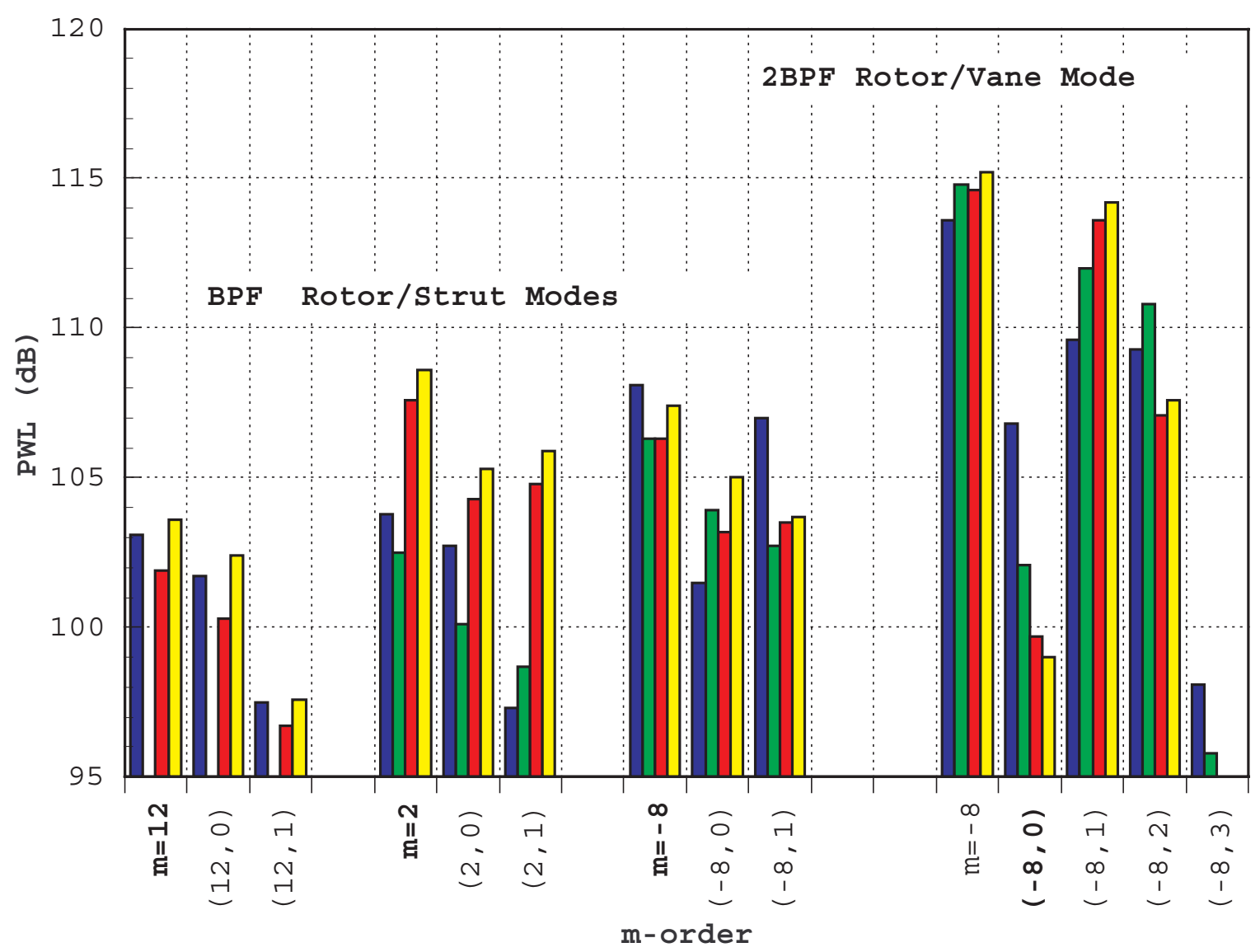

Figure 9. Repeatability of interaction modes in the exhaust (67\% N1C) 
(a) LEVELS MEASURED IN $\mathrm{m}=22 \quad \mathrm{~V}$ tip (fps)

$\begin{array}{llllll}800 & 900 & 1000 & 1100 & 1200 & 1300\end{array}$
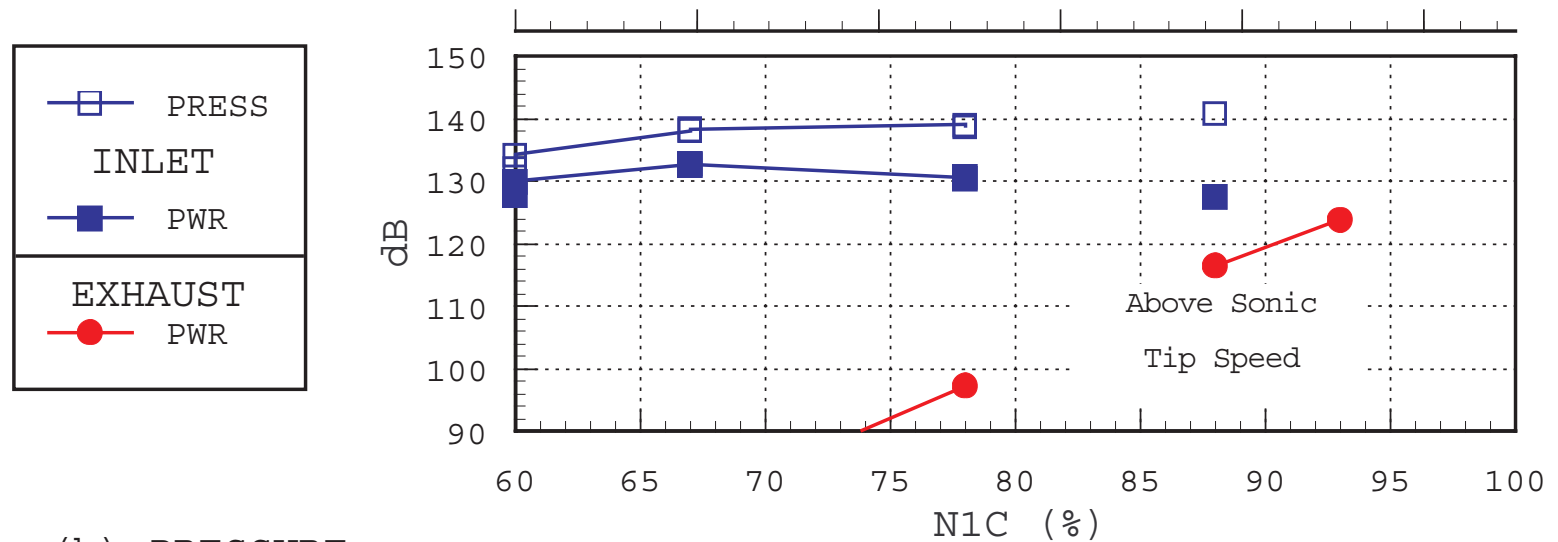

(b) PRESSURE
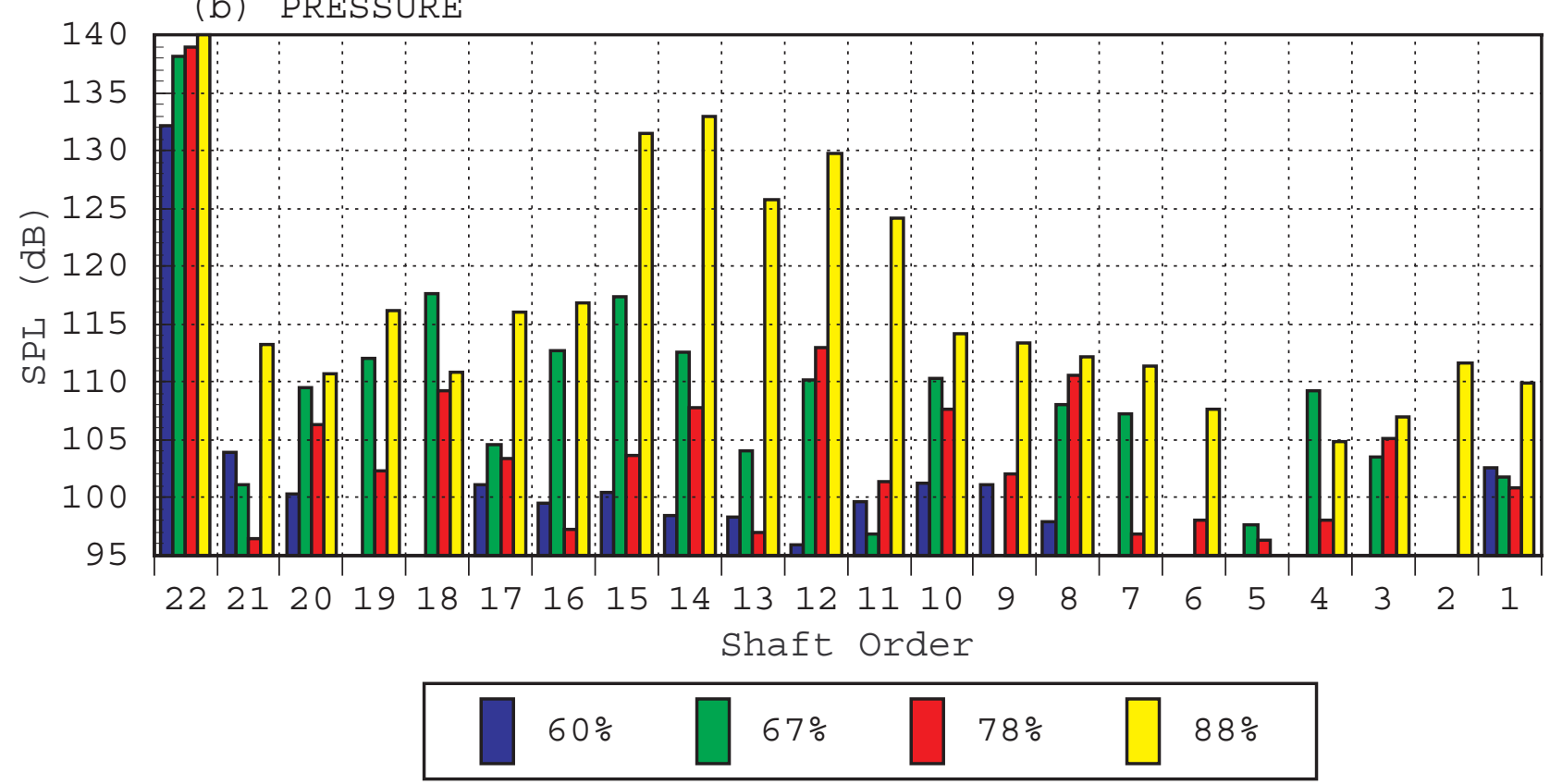

(c) POWER

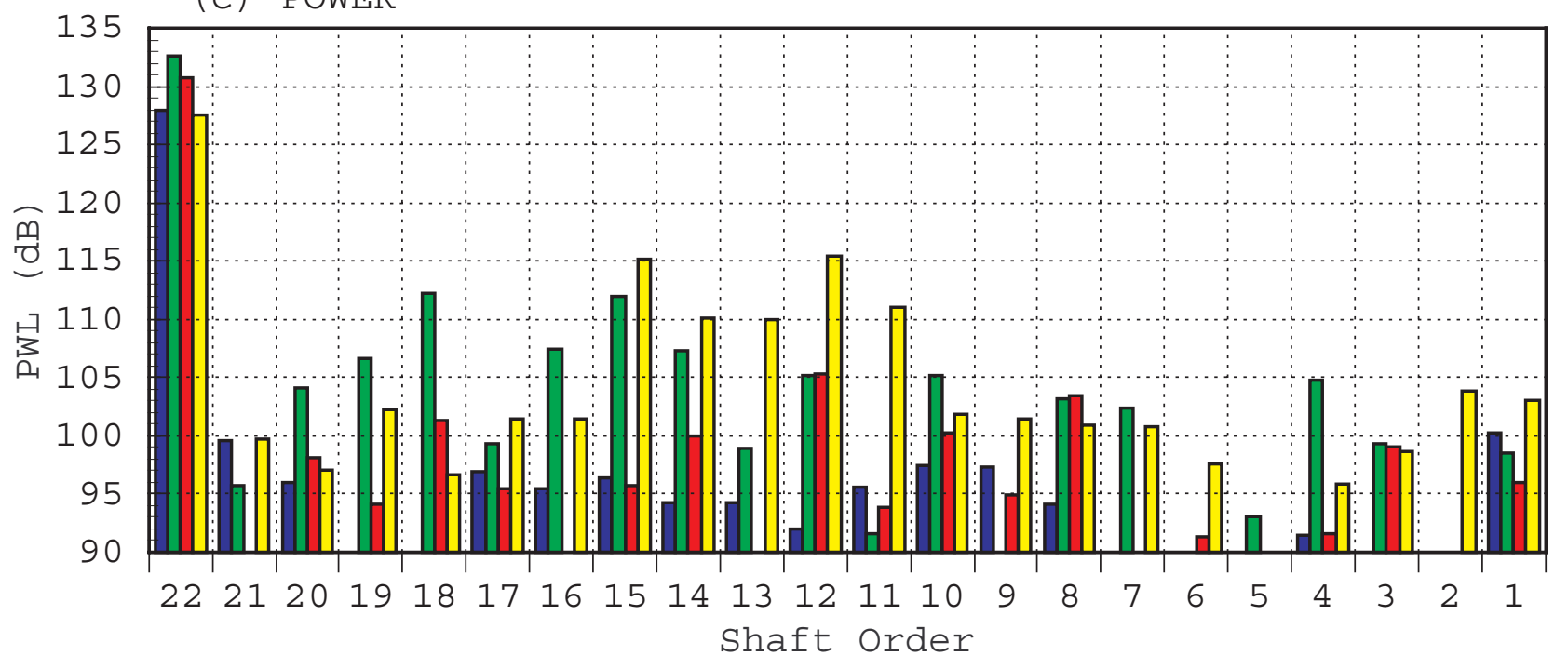

Figure 10. Shaft order analysis 


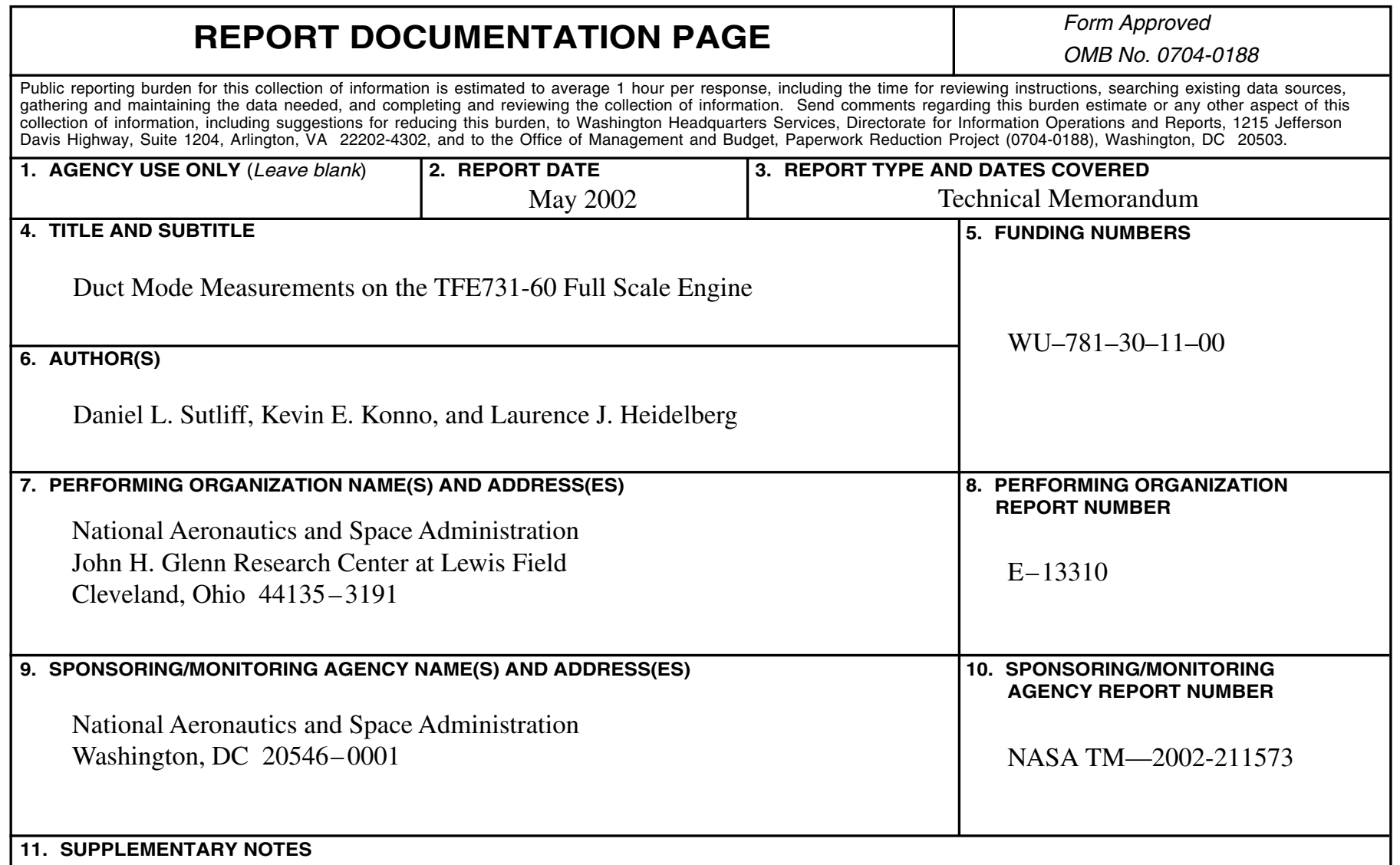

Prepared for the Eighth Aeroacoustics Conference cosponsored by the American Institute of Aeronautics and Astronautics and the Confederation of European Aerospace Societies, Breckenridge, Colorado, June 17-19, 2002. Daniel L. Sutliff, SEST, Inc., Middleburg Heights, Ohio; Kevin E. Konno and Laurence J. Heidelberg, NASA Glenn Research Center. Responsible person, Daniel L. Sutliff, organization code 5940, 216-433-6290.

\begin{tabular}{|l|l|}
\hline 12a. DISTRIBUTION/AVAILABILITY STATEMENT & 12b. DISTRIBUTION CODE
\end{tabular}

Unclassified - Unlimited

Subject Categories: 07 and $71 \quad$ Distribution: Nonstandard

Available electronically at http://gltrs.grc.nasa.gov/GLTRS

This publication is available from the NASA Center for AeroSpace Information, 301-621-0390.

13. ABSTRACT (Maximum 200 words)

A continuously rotating rake with radial microphones was developed to measure the inlet and exhaust duct modes on a TFE731-60 turbofan engine. This was the first time the rotating rake technology was used on a production engine. The modal signature for the first three fan harmonics was obtained in the inlet and exhaust. Rotor-stator and rotor-strut interaction modes were measured. Total harmonic power was calculated over a range of fan speeds. Above sonic tip speed, the rotor locked mode was not strong enough to be identified, but the "buzz-saw" noise at fan sub-harmonics was identified.

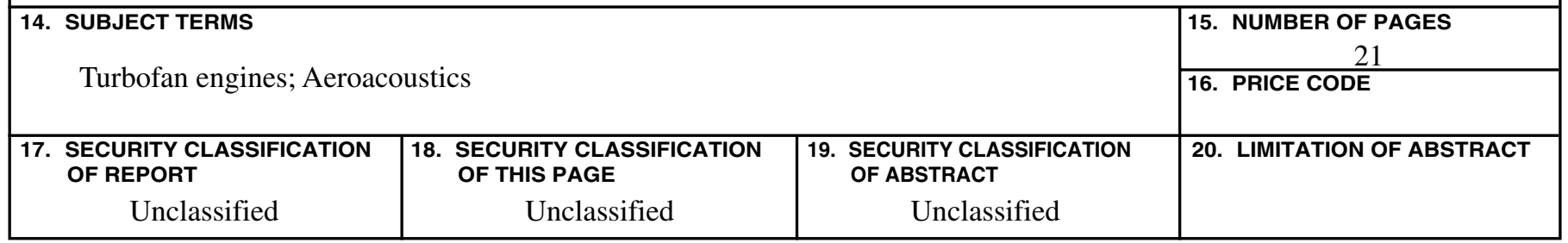

